\title{
CONSCIENTIOUS OBJECTION IN THE COUNCIL OF EUROPE
}

\author{
Fernando Arlettaz ${ }^{1}$
}

\section{Seminario de Investigación para la Paz de Zaragoza, University of Zaragoza, Spain email: arlettaz@unizar.es}

\begin{abstract}
ARLETTAZ, Fernando. Conscientious objection in the Council of Europe. International and Comparative Law Review, 2013, Vol. 13., No. 2, pp. 27-50. DOI: 10.1515/iclr-2016-0069.
\end{abstract}

\begin{abstract}
The Parliamentary Assembly and the Committee of Ministers of the Council of Europe have been promoting the recognition of conscientious objection, mainly for military service but also in other domains, since the 1960s. However, for more than fifty years the precedents of the European Commission and the European Court of Human Rights repeatedly denied that conscientious objection could be found implicit in article 9 of the European Convention on Human Rights. In 2011 the Court changed its standpoint and energetically affirmed that conscientious objection, at least for military service, is a derivation of freedom of conscience and religion, and that European states are thus bound to incorporate it to their internal legislations.
\end{abstract}

Keywords: conscientious objection, freedom of conscience and religion, European Convention on Human Rights

\section{Introduction}

Conscientious objection is a classic matter in studies on freedom of conscience and religion, and conscientious objection to military service has been the case that has received the biggest attention. Many studies have been devoted to the issue, both on the legal and political philosophy field and on the positive law field.

Conscientious objection to military service has a long tradition in the context of the Council of Europe and its member states. The first European country to recognise it was the United Kingdom (1916), followed by Denmark (1917), Sweden (1920), the Netherlands (1920-1923), Norway (1922), Finland (1931), Germany (1949), France (1963), Luxembourg (1963), Belgium (1964), Italy (1972), Austria (1974), Portugal (1976), and Spain (1978). Other countries came after, such as Poland (1988), the Czech Republic (1989), Hungary (1989), Croatia (1990), Estonia (1991), Moldova (1991), Slovenia (1991), Cyprus (1992), the old Federal Republic of Yugoslavia (1992, divided in Serbia and Montenegro, which

1 University of Zaragoza / Seminario de Investigación para la Paz de Zaragoza (Spain). The author thanks Loreto Sainz de Murieta for revising the final version of this article. 
ratified the law in 2006), Ukraine (1992), Latvia (1993), Slovakia (1995), Switzerland (1995), Bosnia and Herzegovina (1996), Romania (1996), Georgia (1997), Greece (1997), and Bulgaria (1998). Macedonia, another of the states arising from the division of Yugoslavia, allowed in 1992 unarmed military service, and in 2001 introduced the right to the civil service as a substitute for military service. Russia constitutionally recognised conscientious objection in 1993, implementing it in 2004. Albania constitutionally recognised it in 1998, implementing it in 2003. Azerbaijan constitutionally recognised the right to conscientious objection in 1995, without having it implemented yet. Turkey does not recognise conscientious objection.

In the majority of states where conscientious objection to military service was or is recognised and fully applied, the status of conscientious objector can be claimed not only on religious basis, but also on the basis of a relatively wide range of personal beliefs of a philosophical nature. The only exceptions are Romania and Ukraine, where the right to claim the status of conscientious objector is limited to religious grounds. When conscientious objector status is granted to someone, he has to perform an alternative service of civil or social nature. Some states, such as Finland, even allow certain categories of people to be exempted not only from military service but also from this alternative service ${ }^{2}$.

After many years of scholarly work on the subject it seemed that there was litthe to say about conscientious objection. However, a 2011 decision of the Grand Chamber of the European Court on Human Rights caused an important change in the Strasbourg's case-law. Striking down the precedents forged by the Commission, and revoking the first instance's decision in the case, the Grand Chamber declared that conscientious objection to military service must be considered implicit in article 9 of the European Convention on Human Rights about freedom of thought, conscience and religion.

Our main aim here is to present this legal mechanism in relation to the Council of Europe's institutions (parts 3 and 4 ). However, it seems necessary to start by defining conscientious objection in a more accurate way (part 2). Finally, we will present some general conclusions (part 5).

\section{Definition of conscientious objection}

Since it is not the purpose of this study to establish a detailed definition of the concept, we shall confine ourselves to some general ideas about the conceptual

2 On conscientious objection, in particular to military service, in the Council of Europe member states see M. STOLWIJK, The Right to Conscientious Objection in Europe: A Review of the Current Situation, 2005, Quaker Council for European Affairs, Brussels; EUROPEAN BUREAU FOR CONSCIENTIOUS OBJECTION: The right to conscientious objection in the Council of Europe Member states, Report to the Council of Europe, 2011, Brussels. EUROPEAN BUREAU FOR CONSCIENTIOUS OBJECTION, Report to the committee on civil liberties, justice and home affairs of the European Parliament, 2012, Brussels. 
problems posed by conscientious objection. For a deeper discussion, please refer to the specialized bibliography ${ }^{3}$.

Conscientious objection can be defined as an exception to the performance of a legal duty granted on grounds of conscience, which may be religious or nonreligious. The main element which would allow to distinguish conscientious objection from other similar concepts is that the former is authorized by a legal provision $^{4}$. In other words, in the case of conscientious objection, the law itself enables the exception for reasons of conscience. The legal norm that establishes the exception can be an explicit text, or a jurisprudential or administrative interpretation from a generic constitutional text.

Thus, conscientious objection can be differentiated from civil disobedience. The latter consists of one or more acts of disobedience to a law which is considered unfair, without a legal authorization to disobey. Civil disobedience is never legally justified. By definition, civil disobedience involves a breach of the law on grounds that the law itself does not admit as valid (if it had admitted them, the rule would have been different and there would have been no need for disobedience).

Of course, the ethical justification of disobedience is a different issue. From an ethical perspective, civil disobedience may or may not be justified according to the circumstances of the case and the goods at stake. Civil disobedience has a long tradition in political thought. Thinkers and activists such as Henry David Thoreau, Mohamed Gandhi and Martin Luther King ${ }^{5}$ provided examples of the theoretical justification and practical implementation of the doctrine of civil disobedience.

3 Many studies have been devoted to the subject, in particular in relation to the different national systems of freedom of conscience and religion. See, for example, D. LAYCOCK, "The religious exemption debate", in Rutgers Journal of Law and Religion, 2009, 11, pp. 140176; M. NUSSBAUM, Liberty of Conscience. In defense of America's Traditions of Religious Equality, 2009, Basic Books, New York; C. TAYLOR and J. MACLURE, Laïcité et liberté de conscience, 2010, La Découverte, París; G. PECES-BARBA (dir.), Ley y conciencia. Moral legalizada y moral crítica en al aplicación del derecho, 1993, Universidad Carlos III, Madrid; F. ARLETTAZ, "Libertad religiosa y objeción de conciencia en el derecho constitucional argentino", in Estudios Constitucionales, 1-2012, pp. 339-372. For a broader approach, see A. SCHINKEL, Conscience and Conscientious Objections, 2007, Vrije Universiteit, Amsterdam. For an international law approach see H. TAKEMURA, International Human Right to Conscientious Objection to Military Service and Individual Duty to Disobey Manifestly Illegal Orders, 2009, Springer, Berlin.

4 G. PECES-BARBA (dir.), op. cit., pp. 12-14. See also, G. PECES-BARBA, "Desobediencia civil y objeción de conciencia”, in Anuario de Derechos Humanos, 1988-1989, 5, pp. 159176.

5 H. D. THOREAU, On the duty of civil disobedience, 1986 [1849], Collier Books, New York; M. GANDHI, Non-violent resistance, 1961 [1951], Schocken Books, New York; M. L. KING, Strenght to love, 1975 [1963], Collins, London. 
Motivation brings up another difference between conscientious objection and civil disobedience. In the case of civil disobedience, the norm is considered as universally unfair, and one disobeys in the hope that others will also do it and so the standard will be modified. This, however, does not necessarily happen in conscientious objection cases: the objector may not have a universal aspiration to change the standard, and may only request it not to be applied in his case because of his particular motives of conscience.

Conscientious objection is exercised precisely for reasons of conscience. Civil disobedience, on the other hand, is based on political motives or, more specifically, is based on ethical (or even religious) reasons presented as political ones. Ethical or religious grounds are exposed as generally valid, so that they would be not only sufficient to justify a single exception to a standard, but even to change the content of that standard in general.

John Rawls has pointed out this feature of conscientious objection, even if he does not consider the element of the legal authorization, which we take as the basis of our distinction, as a part of the concept.

"Conscientious refusal is noncompliance with a more or less direct legal injunction or administrative order. It is refusal since an order is addressed to us and, given the nature of the situation, whether we accede to it is known to the authorities. [...] One's action is assumed to be known to the authorities, however much one might wish, in some cases, to conceal it. Where it can be covert, one might speak of conscientious evasion rather than conscientious refusal. [...] There are several contrasts between conscientious refusal (or evasion) and civil disobedience. [...] Conscientious refusal is not necessarily based on political principles; it may be founded on religious or other principles at variance with the constitutional order. Civil disobedience is an appeal to a commonly shared conception of justice, whereas conscientious refusal may have other grounds. [...] Conscientious refusal may, however, be grounded on political principles. One may decline to go along with a law thinking that it is so unjust that complying with it is simply out of the question. This would be the case if, say, the law were to enjoin our being the agent of enslaving another, or to require us to submit to a similar fate. These are patent violations of recognized political principles"6.

Civil disobedience usually implies disobeying a rule which is considered unfair to obtain its modification. Acting in civil disobedience publicly entails a declaration that one considers that specific legal provision generally unfair, and that there are therefore sufficient reasons not to obey it. On the other hand, exercising a conscientious objection does not have this general intention. One only asks to be exempted from a particular rule, and not this the rule be changed in general.

6 J. RAWLS, A Theory of Justice, 1999 [1971], Harvard University Press, Harvard. 
We have said above that conscientious objection implies an exception for reasons of conscience. This claim, however, must be deeply scrutinised. When the grounds and consequences of conscientious objection are clearly provided by law (for example, in the case of conscientious objection to perform military service the law generally establishes a substitute civil service) the case is similar to the granting of a legal option (a choice between military service and substitute civil service). Even if from a legal point of view it may not be exact to call this a legal option but rather a legal exception, it is nevertheless quite accurate from a realistic perspective to say that there is a choice between two equally legitimate possibilities.

We must clarify that our distinction between conscientious objection and civil disobedience is an ideal one, and that there may be some cases of hybrid character. This would be the case of a legal disobedience on grounds of conscience, without a legal authorization and without having the intention that one's conduct will contribute to a change in the legal system in general. One can think of the classic case of the Jehovah's witnesses that, without an express legal authorization, refused to perform military service and accepted the penalty for it. We could call this case disobedience for conscientious reasons, which is neither a conscientious objection nor a civil disobedience case.

One of the most important problems related to conscientious objection is what the basis for granting those exemptions should be. Many ways are possible here: to grant them on religious grounds only; on both religious and nonreligious grounds; and on non-religious grounds exclusively. The first possibility is maybe the most classic way to proceed. It is the one adopted, at least formally, by the United States Constitution and its interpretative case-law. According to the first amendment, Congress cannot limit the freedom of religion. So religion is given particular consideration in American Constitutional Law, and the Supreme Court has developed the idea that religious convictions merit to be accommodated if they collide with general and apparently neutral regulations.

Martha Nussbaum has defended this kind of accommodation of religious convictions. According to her, "although accommodation seems in some cases to pose a problem of fairness, considerations of both fairness and liberty strongly support the practice of granting accommodations, in at least some cases. When Christians may observe the day of rest that their religion requires, without loss of job or unemployment benefits, but those who observe a different day of rest may not, there is a burden on the liberty of these minorities to practice their religion"?.

7 M. NUSSBAUM, op. cit., p. 118. Bedi argues that the only way to grant an exemption on religious grounds is to consider that religion is a primordial commitment of the individual that have not been freely chosen. See S. BEDI, "Debate: What is so Special about Religion? The Dilemma of the Religious Exemption", in The Journal of Political Philosophy, 2007, 15-2, pp. 235-249 
This approach has been strongly criticised, since it may disfavour non-religious commitments that can be as strong and respectable as religious ones (for example those of non-religious pacifists that refuse conscription). To overcome this obstacle, Nussbaum has suggested that, as religion concerns what one might call the ultimate questions of life, we should extend the concept of religion to all the activities that deal with such questions, even if they are not usually qualified as religions ${ }^{8}$. Many scholars consider this to be a wrong way to grant exemptions. For them, religion is not special, and so it should not be granted a special status?

Another way to proceed, and the most usual one in fact, is to grant exemptions on grounds of conscience, either religious or non-religious. This option has the intrinsic problem that it relies on an internal psychological state that can refer to anything a person cares about. Religious convictions, on the contrary are much easily identified as they have a collective dimension and a historical foundation ${ }^{10}$.

A few scholars, like Yosse Neushatan, have developed yet another way to proceed, even if this is a rather unusual position. For them, the state should almost always express an attitude of intolerance towards intolerant conscientious objectors. This could be done in various ways. The authorities may grant them an exemption but condemn their values or behaviour. The authorities may also grant them an exemption and, at the same time, deny them any governmental support or subsidy. In appropriate cases, the authorities may also refuse to grant an exemption. This anti-religious approach is based on the idea that unjustified intolerance should not be tolerated, and that there is an empirical and theoretical link between religion and intolerance ${ }^{11}$. The anti-religious approach has been

8 M. NUSSBAUM, op. cit., pp. 168-170.

9 F.M. GEDICKS, "An Unfirm Foundation: The Regrettable Indefensibility of Religious Exemptions", University of Arkansas at Little Rock Law Journal, 1998, 20, p. 562; W.P. MARSHALL, "The Case Against the Constitutionally Compelled Free Exercise Exemption", Case Western Reserve Law Review, 1990, 40, pp. 383-384; K. GREENAWALT, Conflicts of Law and Morality, 1989, p. 324.

10 A. KOPPELMAN, "Conscience, volitional necessity, and religious exemptions", in Legal Theory, 2009, 15, pp. 215-244.

11 Y. NEUSHATAN, "Religious conscientious exemptions", in Law and Philosophy, 2011, 30, pp. 164-165. Nehushtan distinguishes two options. According to the narrow thesis, if claims for religious-conscientious exemptions are based directly on intolerant values, beliefs and conscience, or on values that utterly undermine the rationales for tolerance, the state has a strong, normally prevailing reason not to grant the exemption. According to the broad thesis, the state has a good reason, although not necessarily a prevailing one, not to grant religious conscientious exemptions, even in cases where the claims to be granted exemptions are not based directly on intolerant values, beliefs or conscience. The state may have such a reason because of the special links between certain religions and intolerance. The stronger the link regarding a certain religion, the stronger is the reason not to grant religious conscientious exemptions to its adherents. The broad thesis assumes that the tolerant-liberal state has a right both to strengthen its liberal, secular nature and to discourage its citizens from choosing a religious way of life. Nehushtan admits that he 
strongly criticised from an equal respect point of view. Martha Nussbaum, for example, has said that this kind of anti-religionism is not compatible with a thoroughgoing commitment to equal respect ${ }^{12}$.

In the following two sections we will address conscientious objection in relation to the Council of Europe institutions. One main point to be considered, in the context of human rights theory, is whether or not conscientious objections can be understood as implicit in general clauses about freedom of conscience and religion. Should this question be positively answered, judges could decide that individuals can be exempted from complying with legal duties without a particular legal authorization. A general provision, for example a constitutional clause granting religious freedom, could be considered sufficient. On the other hand, if the question was negatively answered, the exemptions could be granted only in the case that a legal authorization provided so. As we will see, this point is of particular importance in the analysis of European case-law.

\section{Conscientious objection in the Council of Europe: the documents of the Parliamentary Assembly and the Committee of Ministers of the Council of Europe}

Many institutions of the Council of Europe have mentioned the right to conscientious objection in their documents. In this part we will present a chronological overview of the Recommendations of the Committee of Ministers, as well as the Resolutions and Recommendations of the Parliamentary Assembly.

The Committee of Ministers is the Council of Europe's decision-making body. According to article 15.b of the Statute of the Council of Europe, the Committee can make recommendations to member states about matters on which it has agreed a common policy. These recommendations, however, are not binding on member states ${ }^{13}$. On the other hand, the Parliamentary Assembly is composed of national representatives elected by national Parliaments among their members. Its recommendations contain proposals addressed to the Committee of Ministers, the implementation of which is within the competence of governments; its resolutions embody decisions by the Assembly on questions which it is empowered to put into effect, or mere expressions of view as the ones cited below.

tends to favour the broad rather than the narrow thesis.

12 M. NUSSBAUM, "Liberty of Conscience: The Attack on Equal Respect", in Journal of Human Development, 2007, 8, p. 355.

13 On the legal status of recommendations see G. PUPPINCK, Status of the recommendations of the Committee of Ministers in the legal field of the Council of Europe, document prepared for the European Centre for Law and Justice, 2012, http://eclj.org/PDF/status-ofthe-recommendations-of-the-committee-of-ministers-in-the-legal-field-of-the-councilof-europe $\% \mathrm{E} 2 \% 80 \% 93$ synthesis-english.pdf. 
The first document to be mentioned is Resolution 337 (1967) of the Parliamentary Assembly of the Council of Europe. It established the principle that states should grant conscientious objector status to those persons who refused to perform military service both on religious and philosophical grounds:

"Persons liable to conscription for military service who, for reasons of conscience or profound conviction arising from religious, ethical, moral, humanitarian, philosophical or similar motives, refuse to perform armed service shall enjoy a personal right to be released from the obligation to perform such service"14.

Moreover, the Resolution declared that the right was implicit in article 9 of the European Convention ${ }^{15}$. This declaration was of great importance, because if the right to conscientious objection (at least for military service) was indeed implicit in article 9, the European Court or the European Commission of Human Rights could find a violation of European standards in the practices of those states that do not protect that right. As we will see, neither the European Court nor the European Commission shared the Parliamentary Assembly opinion.

These basic principles were followed, in the same Resolution, by procedural rules: the obligation of the state to inform persons liable for military service about the right they can exercise; the impartiality of authorities that must decide about conscientious objection and the control of administrative decisions by other administrative bodies as well as judicial ones; the suspensive effect of objections and judicial appeals; the right of the applicants to be granted a hearing ${ }^{16}$.

14 Resolution of the Parliamentary Assembly 337 (1967) on the right of conscientious objection, point A.1.

15 Resolution of the Parliamentary Assembly 337 (1967) on the right of conscientious objection, point A.2: "This right shall be regarded as deriving logically from the fundamental rights of the individual in democratic Rule of Law states which are guaranteed in Article 9 of the European Convention on Human Rights".

16 Resolution of the Parliamentary Assembly 337 (1967) on the right of conscientious objection, point B: "1. Persons liable for military service should be informed, when notified of their call-up or prospective call-up, of the rights they are entitled to exercise.

"2. Where the decision regarding the recognition of the right of conscientious objection is taken in the first instance by an administrative authority, the decision-taking body shall be entirely separate from the military authorities and its composition shall guarantee maximum independence and impartiality.

" 3 . Where the decision regarding the recognition of the right of conscientious objection is taken in the first instance by an administrative authority, its decision shall be subject to control by at least one other administrative body, composed likewise in the manner prescribed above, and subsequently to the control of at least one independent judicial body.

" 4 . The legislative authorities should investigate how the exercise of the right claimed can be made more effective by ensuring that objections and judicial appeals have the effect of suspending the armed service call-up order until the decision regarding the claim has been rendered.

"5. Applicants should be granted a hearing and should also be entitled to be represented and to call relevant witnesses". 
Finally, the Parliamentary Assembly established some rules on the alternative service. According to these rules, the alternative service must be at least as long as the military service, both must have the same social and financial conditions and conscientious objectors must be employed in works of national importance ${ }^{17}$.

Later on, through its Recommendation 478 (1967), the Parliamentary Assembly asked the Committee of Ministers to invite member states to adapt their legislations to these principles, and instructed the Committee of Experts on Human Rights to formulate proposals to give effect to the principles laid down by the Assembly. The Parliamentary Assembly reiterated its position in its Recommendation 816 (1977) which asked the Committee of Ministers to urge the governments of member states, in so far as they had not already done so, to bring their legislation into line with the principles adopted by the Assembly, and to introduce the right of conscientious objection to military service into the European Convention on Human Rights ${ }^{18}$.

Following the Parliamentary Assembly recommendations, the Committee of Ministers adopted in 1987 Recommendation $\mathrm{R}(87) 8$, encouraging member states to recognise the right to conscientious objection to military service and inviting the governments which had not yet done so to bring their national law and practice into line with the following basic principle:

"Anyone liable to conscription for military service who, for compelling reasons of conscience, refuses to be involved in the use of arms, shall have the right to be released from the obligation to perform such service [...] Such person may be liable to perform alternative service"19.

The principle was followed by some procedural rules for the examination of the application for conscientious objection ${ }^{20}$; and by some principles on the

17 Resolution of the Parliamentary Assembly 337 (1967) on the right of conscientious objection, point C: "1. The period to be served in alternative work shall be at least as long as the period of normal military service.

" 2 . The social and financial equality of recognised conscientious objectors and ordinary conscripts shall be guaranteed.

"3. The Governments concerned shall ensure that conscientious objectors are employed in social work or other work of national importance - having regard also to the manifold needs of the developing countries".

18 Recommendation of the Parliamentary Assembly 478 (1967) on the right of conscientious objection and Recommendation of the Parliamentary Assembly 816 (1977) on the right of conscientious objection to military service. The second Recommendation was accompanied by an annex on the Principles relating to the right of conscientious objection to military service, which reproduced the content of Resolution of the Parliamentary Assembly 337 (1967).

19 Recommendation of the Committee of Ministers $\mathrm{R}(87) 8$ regarding conscientious objection to military service, point 1 .

20 Recommendation of the Committee of Ministers $\mathrm{R}(87) 8$ regarding conscientious objection to military service: "2. States may lay down a suitable procedure for the examination of applications for conscientious objector status or accept a declaration giving reasons by 
alternative service ${ }^{21}$, very similar to those that had been set in the Parliamentary Assembly Resolution quoted above. Some states, however, reserved the right not to comply with the Recommendation, according to the rules of the Committee of Ministers ${ }^{22}$. One state declared that the Recommendation fell short of the Parliamentary Assembly Recommendation, and was therefore deficient ${ }^{23}$. Indeed, as it has been pointed out ${ }^{24}$, the Committee of Ministers Recommendation avoided the identification of conscientious objections as a derivation of freedom of thought, conscience and religion.

In June 1993, the Committee on Legal Affairs and Human Rights submitted a draft recommendation on the right of conscientious objection to military service to the Parliamentary Assembly, but this and the accompanying report were sent back for further discussion and redrafting ${ }^{25}$. More recently, in its Recommendation 1518 (2001), the Parliamentary Assembly recalled that the exercise of the

the person concerned;

"3. With a view to the effective application of the principles and rules of this recommendation, persons liable to conscription shall be informed in advance of their rights. For this purpose, the state shall provide them with all relevant information directly or allow private organisations concerned to furnish that information;

"4. Applications for conscientious objector status shall be made in ways and within timelimits to be determined having due regard to the requirement that the procedure for the examination of an application should, as a rule, be completed before the individual concerned is actually enlisted in the forces;

"5. The examination of applications shall include all the necessary guarantees for a fair procedure;

"6. An applicant shall have the right to appeal against the decision at first instance;

"7. The appeal authority shall be separate from the military administration and composed so as to ensure its independence;

" 8 . The law may also provide for the possibility of applying for and obtaining conscientious objector status in cases where the requisite conditions for conscientious objection appears during military service or periods of military training after initial service".

21 Recommendation of the Committee of Ministers $\mathrm{R}(87) 8$ regarding conscientious objection to military service: "9. Alternative service, if any, shall be in principle civilian and in the public interest. Nevertheless, in addition to civilian service, the state may also provide for unarmed military service, assigning to it only those conscientious objectors whose objections are restricted to the personal use of arms;

"10. Alternative service shall not be of a punitive nature. Its duration shall, in comparison to that of military service, remain within reasonable limits;

"11. Conscientious objectors performing alternative service shall not have less social and financial rights than persons performing military service. Legislative provisions or regulations which relate to the taking into account of military service for employment, career or pension purposes shall apply to alternative service".

22 Greece reserved the right to comply or not with the text. Cyprus reserved the right to comply or not with point 9 . Switzerland and Turkey recorded their abstention and declared that they would be unable to comply.

23 Italy.

24 H. TAKEMURA, cit., pp. 90-91.

25 Doc. 6752, report of the Committee on Legal Affairs and Human Rights (Rapporteur: Mr Rodotà). 
right of conscientious objection to military service had been an ongoing concern of the Council of Europe for over thirty years. It further added that the right to conscientious objection was a "fundamental aspect of the right to freedom of thought, conscience and religion" enshrined in the Universal Declaration of Human Rights and in the European Convention on Human Rights. It recognised that even if all but five countries of the Council had introduced the right to conscientious objection in their constitutions or legislation, the position of conscientious objectors still differed considerably from one country to another, and differences in the law resulted in varying levels of protection. The Parliamentary Assembly consequently recommended the Committee of Ministers to invite those member states that had not yet done so to introduce into their legislation the right to be registered as a conscientious objector at any time, even for permanent members of the armed forces; as well as the right for all conscripts to receive information on conscientious objector status and the means of obtaining it and the right to perform a genuine alternative service of a clearly civilian nature, which should be neither deterrent nor punitive in character ${ }^{26}$.

The Assembly also reiterated its recommendation to the Committee of Ministers to "incorporate the right of conscientious objection to military service into the European Convention on Human Rights by means of an additional protocol amending Articles 4.3.b and 9"27.

The report of the Committee of Legal Affairs and Human Rights preceding that Recommendation had stated that the right of conscientious objection was thus moving towards full acceptance in Europe. It was being strengthened in both quantitative and qualitative terms. In quantitative terms, many European states had accepted it, although three South-Eastern European countries (Turkey, Albania and the Former Yugoslav Republic of Macedonia) and two Caucasian countries (Armenia and Azerbaijan) had not. Most states which had recognised this right had also introduced alternative civilian service to replace military service (although Cyprus and Russia had no laws setting up genuine alternative service). In qualitative terms, many existing laws had been improved with regard to the examination of applications by objectors, the length and conditions of civilian service, and objectors' rights. According to the Committee, these developments had to be considered consistent with the new requirements of international $\operatorname{law}^{28}$.

In 2006 the Parliamentary Assembly adopted Recommendation 1742 (2006) concerning human rights of members of the armed forces. In this Recommenda-

26 Recommendation of the European Parliament 1518 (2001) on the exercise of the right of conscientious objection to military service in Council of Europe member states, point 5 .

27 Recommendation of the European Parliament 1518 (2001) on the exercise of the right of conscientious objection to military service in Council of Europe member states, point 6 .

28 Doc. 8809 revised, report of the Committee on Legal Affairs and Human Rights (Rapporteur: Mr Marty). 
tion the Assembly recalled that the right of conscientious objection is an essential component of the right to freedom of thought, conscience and religion. It called upon the member states to introduce into their legislation the right to be registered as a conscientious objector at any time (before, during or after military service) and the right of career servicemen to be granted such status. It once again recommended the Committee of Ministers to reconsider its proposal to introduce the right to conscientious objection to military service into the European Convention on Human Rights by means of an additional protocol amending Articles 4.3.b and $9^{29}$.

In 2010 the Committee of Ministers passed Recommendation CM/ $\operatorname{Rec}(2010) 4$, which recalled that members of military forces had the right to freedom of thought, conscience and religion, and recommended the member states to ensure that any limitations on the right to freedom of thought, conscience and religion of members of the armed forces comply with the requirements of Article 9.2 of the Convention. In consequence, conscripts should have the right to be granted conscientious objector status, and professional members of the armed forces should be able to leave the armed forces for reasons of conscience. Requests by members of the armed forces to leave the armed forces for reasons of conscience should be examined within a reasonable time, and if they were denied they should be examined by an independent and impartial body. Members of the armed forces having legally left the armed forces for reasons of conscience should not be subject to discrimination or to any criminal prosecution. All members of the armed forces should be informed of these rights ${ }^{30}$.

In the explanatory Memorandum of this Recommendation, the Steering Committee for Human Rights avowed that the right to conscientious objection had not yet been recognised by the Court as being covered by Article 9 of the Convention. However, it declared that the current trend in international fora was to consider it part and parcel of the freedom of conscience and religion. The Steering Committee reminded that the right to conscientious objection for conscripts had been recognised by the great majority of member states. Indeed, most countries had passed laws setting up procedures for the processing of applications for exemption from military service, and generally providing for the performance of alternative service by those who were exempt.

Even though military service has been the domain to which more attention has been paid, the Council of Europe has also considered conscientious objection in other fields. Indeed, in 2010 the Parliamentary Assembly passed Resolu-

29 Recommendation of the Parliamentary Assembly 1742 (2006) on Human Rights of members of the armed forces, especially points 8, 9.7 and 11.1 .

30 Recommendation of the Committee of Ministers CM/Rec(2010)4 on Human Rights of members of the armed forces, especially points 41 to 46 . 
tion 1763 (2010) on the right to conscientious objection in lawful medical care ${ }^{31}$. According to this resolution:

"No person, hospital or institution shall be coerced, held liable or discriminated against in any manner because of a refusal to perform, accommodate, assist or submit to an abortion, the performance of a human miscarriage, or euthanasia or any act which could cause the death of a human foetus or embryo, for any reason"32.

Consequently, the Parliamentary Assembly invited the member states to "develop comprehensive and clear regulations that define and regulate conscientious objection with regard to health and medical services, which:

1. Guarantee the right to conscientious objection in relation to participation in the procedure in question;

2. Ensure that patients are informed of any objection in a timely manner and referred to another healthcare provider;

3. Ensure that patients receive appropriate treatment, in particular in cases of emergency"33.

4. Conscientious objection in the Council of Europe: the European Commission on Human Rights and the European Court of Human Rights

On this section we will focus on two different aspects of our subject, presenting first the former criterion of the European Commission on Human Rights, which had been tacitly validated by the European Court of Human Rights; and then the new criterion of the Court ${ }^{34}$.

31 On conscientious objection in medicine see, generally, M. WICCLAIR, "Conscientious objection in medicine", in Bioethics, 2000, 14-3, pp. 205-227. About the particular Resolution see M. CAMPBELL, "Conscientious objection and the Council of Europe: The right to conscientious objection in lawful medical care", in Medical Law Review, 2011, 19, pp. 467-475.

32 Resolution 1763 (2010) on the right to conscientious objection in lawful medical care, point 1 . The rest of the Resolution reads as follows:

"2. The Parliamentary Assembly emphasises the need to affirm the right of conscientious objection together with the responsibility of the state to ensure that patients are able to access lawful medical care in a timely manner. The Assembly is concerned that the unregulated use of conscientious objection may disproportionately affect women, notably those having low incomes or living in rural areas.

"3. In the vast majority of Council of Europe member states, the practice of conscientious objection is adequately regulated. There is a comprehensive and clear legal and policy framework governing the practice of conscientious objection by healthcare providers ensuring that the interests and rights of individuals seeking legal medical services are respected, protected and fulfilled".

33 Resolution 1763 (2010) on the right to conscientious objection in lawful medical care, point 4.

34 About the European case-law on religious freedom see, among many others, F. ARLETTAZ, La jurisprudencia del Tribunal Europeo de Derechos Humanos sobre la libertad religiosa: un análisis jurídico-político, in Derechos y Libertades, 2012, 27, pp. 209-240. A.

\section{(c) Palacký University Olomouc, Czech Republic, 2013. ISSN 1213-8770 (print), ISSN: 2464-6601 (online).}




\subsection{The former criterion of the Commission and the Court}

The initial position regarding conscientious objection was set up by the now disappeared European Commission on Human Rights, in a case in which a Jehovah's Witness had asked to be exempted not only from military service but also from substitute civil service, alleging a violation of article 9. The claimant interpreted that the authorities had imposed him a service that was contrary to his conscience, and had punished him for refusing to comply with such a service.

The Commission held, in the first place, that since the performance of the substitute civil service did not occupy all the useful time of the claimant, there was no interference with his freedom of religion, because he could continue his ministerial activities in his spare time:

"In the Commission's opinion, it also appears from the facts established in this case $[\ldots]$ that the nature of the compulsory service which would have been imposed upon the applicant would have been such as to leave him sufficient time to perform his duties towards his religious community. [...] Consequently, in the Commission's opinion, the service required of the Applicant would not have implied any interference with his 'freedom [...] to manifest his religion or belief, in [...] teaching' within the meaning of Article 9, paragraph (1), of the Convention" 35 .

Also, and this would be truly relevant in subsequent cases, the Commission concluded that although article 9 guarantees the right to freedom of conscience and religion, it is article 4 of the Convention which must be applied in relation to services that are compulsively demanded in place of military service. Since this article expressly recognises that a substitute civil service can be imposed, there is no place to interpret that there is a right protected by article 9 to be exempted from this service:

"As in this provision it is expressly recognised that civilian service may be imposed on conscientious objectors as a substitute for military service, it must

CHUECA SANCHO, El derecho humano a la libertad de religión y convicciones en una Europa intercultural, in VVAA, Teoría de la justicia y derechos fundamentales, 2008, Dikynson, Madrid, pp. 297-318. C. EVANS, Freedom of religion under the European Convention on Human Rights, 2003, Oxford University Press, Oxford. J. MARTÍNEZ-TORRÓN, Los límites a la libertad de religión y de creencia en el Convenio Europeo de Derechos Humanos, in Revista General de Derecho Canónico y Derecho Eclesiástico del Estado, 2003, 2. R. RYSSDAL, Religious Freedom in the case law of the European Court of Human Rights, in J. MARTÍNEZ-TORRÓN, La libertad religiosa y de conciencia ante la justicia constitucional, 1998, Granada, pp. 87-93. P. TAYLOR, Freedom of religion. UN and European Human Rights law and practice, 2005, Cambridge University Press, Cambridge.

35 European Commission on Human Rights (hereinafter, Commission): Grandrath v. Germany $(12 / 12 / 1966)$, p. 31. 
be concluded that objections of conscience do not, under the Convention, entitle a person to exemption from such service"36.

This case raised yet another problem. German law allowed the ministers of certain confessions to be exempted both from military service and from substitute civil service. In particular, German law exempted Catholic and Evangelical ministers, with the only condition that they were ordered. Ministers of other religions could also be exempted from both services, but they had to prove the fulfilment of two requirements: 1) that the activity of religious minister was their main occupation; 2) that they carried out tasks equivalent to those of the Catholic and Evangelical ministers.

The Commission concluded that German law, either abstractly considered or considered as applied in this case, was in accordance with the principle of nondiscrimination enshrined in article 14 of the Convention. First because the distinction established by German law could be considered legitimate, since it was intended to prevent a general evasion of the duty to comply with military service, granting the double exemption only to those religious ministers whose activity required it. Second, because in the case the claimant had admitted that before being summoned to military service, he served in a common employment, so that he was devoted to religious tasks only in his free time.

In a different case, related to the objection to the military service itself (and not to all compulsory service, both civil and military), the Commission recognised that article 9 should be interpreted in relation to other articles of the Convention, in particular article 4.3.b. According to the latter, the concept of forced labour does not include military service, nor substitute civil service in those countries that admit such civil service as a substitute of military service. By adding this last expression, the Convention was making clear that there is not a legal duty of states to recognise exceptions to the military service for reasons of conscience, but that it is simply a faculty.

"This provision clearly shows that, by including the words in countries where they are recognised' in Art. 4.3.b, a choice is left to the High Contracting Parties to the Convention whether or not to recognise conscientious objectors and, if so recognised, to provide some substitute service for them. The Commission, for this reason, finds that art. 9, as qualified by art. 4.3.b of the Convention, does not impose on a state the obligation to recognise conscientious objectors and, consequently, not to make special arrangements for the exercise of their right to freedom of conscience and religion as far as it affects their compulsory military service" 37 .

After the two above mentioned cases, the Commission reiterated in many others that conscientious objection to military service is not implicit in article

36 Commission: Grandrath v. Germany (12/12/1966), p. 32.

37 Commission: G. Z. v. Austria (02/04/1973), decision on inadmissibility, p. 1. 
$9^{38}$. It also noted that in those systems that allow to be exempted from military service performing a substitute civil service there is no right to be exempted from the latter on grounds of conscience ${ }^{39}$.

The main criticism to be potentially addressed to this standpoint is that even if according to article 4.3.b an individual may be liable for military or civil service, this is not incompatible with the idea that if those services are refused for conscience reasons they can only be coercively imposed respecting the provisions of article 9.2 about the limits of freedom of conscience and religion. However, had the Commission adopted this point of view it would have probably accepted that military or civil service are legitimate limitations of the fundamental freedom enshrined in article $9^{40}$.

The Commission also said that it does not constitute discriminatory treatment that alternative civil service is longer than military service. There is, therefore, no violation of the principle of equality as enshrined in article 14 of the Convention:

"The Commission considers that, in certain respects, someone who has opted to do a substitute civilian service is in a comparable position to someone who has to do military service. To this extent there was a differential treatment in the present case. The Commission has had regard to the reasons given for this differential treatment by the Dutch courts, viz. that substitute civilian service is generally considered as less arduous and that there was a need to avoid refusal of military service for that reason. In addition, the Commission notes the courts' finding that these criteria also applied to the applicant and that the additional time the latter had to serve was reasonably proportional to the different nature of the two different services. In view of the reasons given by the domestic courts, the Commission is satisfied that the difference in treatment, consisting of the longer period of substitute civilian service as compared with ordinary military service, had a legitimate aim and was proportional to the aim sought to be realised" ${ }^{\prime 1}$.

It is not discriminatory either that the pay of those who perform military service is greater than that of those performing civil service, since article 14 applies only in relation to other rights recognised in the Convention, and the Convention does not recognise a right to be paid for military or civilian services ${ }^{42}$.

38 Commission: Crespo-Azorín v. Spain (17/05/1990), decision on inadmissibility. Commission: Musy v. Switzerland (08/01/1993), decision on inadmissibility. Commission: Olcina Portilla v. Spain (14/10/1996), decision on inadmissibility. Commission: Chardonneau v. France (29/06/1992), decision on inadmissibility.

39 Commission: $X$ v. Germany (05/07/1977), decision on inadmissibility. Commission: Johansen v. Norway (14/10/1985). Commission: Autio v. Finland (06/12/1991). Commission: A. v. Switzerland (09/05/1984), decision on inadmissibility.

40 M. EVANS, Religious liberty and international law in Europe, 1997, Cambridge University Press, Cambridge.

41 Commission: G. v. Holland (02/03/1987), decision on inadmissibility, p. 1.

42 Commission: Conscientious objectors v. Denmark (07/03/1977). 
Requests for conscientious objection have also been submitted in other areas. For example, the Commission faced a claim according to which the obligation to pay an income tax that was intended in part to the financing of military research would imply an interference with the freedom of conscience. The applicant was a member of the Religious Society of Friends (Quakers), one of whose central tenets is pacifism. He was not willing to pay that proportion of his taxes which was used to finance military research. The Commission ruled out the feasibility of conscientious objection in this case, since the tax was established by neutral legislation at the level of consciousness.

"The obligation to pay taxes is a general one which has no specific conscientious implications in itself. Its neutrality in this sense is also illustrated by the fact that no tax payer can influence or determine the purpose for which his or her contributions are applied, once they are collected. Furthermore, the power of taxation is expressly recognised by the Convention system and is ascribed to the state by article 1, First Protocol. It follows that article 9 does not confer on the applicant the right to refuse, on the basis of his convictions, to abide by legislation, the operation of which is provided for by the Convention, and which applies neutrally and generally in the public sphere, without impinging on the freedoms guaranteed by article 9. If the applicant considers the obligation to contribute through taxation to arms procurement an outrage to his conscience he may advertise his attitude and thereby try to obtain support for it through the democratic process" ${ }^{33}$.

It is interesting to note that, to prevent a possible negative response of the Commission, the claimant had expressly held that his application was not a case of conscientious objection.

In other cases, the Commission also rejected the objection of conscience. It ruled that conscientious objection could not be invocated to be exempted from the payment of contributions to social security. The Dutch social security system admitted the possibility of invoking conscientious objection in order not to pay the pension insurance contributions. However, there were two conditions: 1) that the person could demonstrate that, for reasons of conscience, he was opposed to any form of insurance; 2) that the person paid a plus on the income tax. Those who chose to object would not receive a pension, but a certain sum of money under another concept at the time of retirement.

The claimant was a Dutch citizen belonging to a reformed church which held that, for religious reasons, he had objections to the pension insurance system. However, he did not comply with the conditions prescribed by law, since he did not object all insurance system. Furthermore, he was not willing to pay the plus of the income tax. The Commission rejected the conscientious objection ${ }^{44}$.

43 Commission: C. v. United Kingdom (15/12/1983), p. 1.

44 Commission: $X$ v. Holland (14/12/1965). 
Until recently there had been no conclusive case-law of the Court in the sense of denying the objection within the framework of the Convention. The European Court had incidentally mentioned the objection of conscience in cases in which the central issue was a different one ${ }^{45}$. In those cases in which the core of the issue was linked to conscientious objection, the Court had eluded to discuss the main problem, and had ruled the case either by application of clauses other than article 9 of the Convention, or by application of article 9 itself without referring to whether conscientious objection was or not included therein.

Thus, in the Thlimmenos case a Greek national belonging to the Jehovah's Witnesses group had alleged a violation of freedom of conscience and the equality principle in relation to this freedom ${ }^{46}$. Greek law did not recognise conscientious objection and Mr Thlimmenos had refused to perform military service, so he had been sentenced for insubordination. Years later, Thlimmenos tried to register as an accountant in the corresponding professional institution. The registration was denied because of the existence of a previous criminal conviction. The Court, without going into the question of whether the criminal conviction had been legitimate or illegitimate (that is without deciding if Thlimmenos would have had or not a right to conscientious objection in the past), considered that preventing the registration as an accountant to someone who had been sentenced because of his religious convictions (and not for example, because of a scam or an act of fraud) constituted a violation of article 14 of the Convention in relation to article 9 .

In the Ülke case, relating to a conscientious objector repeatedly condemned, the Court judged that there had been a violation of article 3 by the existence of degrading treatment, without considering article 9 on religious freedom ${ }^{47}$. Another case about conscientious objection, Stefanov, was struck out of the list of the Court following a friendly settlement ${ }^{48}$. Finally, in the Glor case the Court found a violation of article 14 (prohibition of discrimination) in relation to article 8 (protection of private life) in the fact that some people, exempted from the military service for health reasons, had to pay an exemption tax. In this case, the Court did not considered exemptions based on conscientious objection ${ }^{49}$.

There was a case in which the Court was very close to address the issue of conscientious objection. The Pichon and Sajous case was based on the demand of a group of chemists who had refused to sell birth control pills because of their religious beliefs. The Court ruled that there was no interference with their reli-

45 European Court of Human Rights (hereinafter, Court): De Jong, Baljet and Van Den Brink v. Holland (22/05/1984). Court: Van der Sluijs, Zuiderveld and Klappe v. Holland (22/05/1984). Court: Duinhof and Duijfv. Holland (22/05/1984). Court: Pantoulias v. Greece (18/01/2007), decision on inadmissibility. Court: Löffelmann v. Austria (12/03/2009).

Court: Lang v. Austria (19/03/2009).

46 Court: Thlimmenos v. Greece (06/04/2000).

47 Court: Ülke v. Turkey (24/01/2006).

48 Court: Stefanov v. Bulgaria (03/05/2001).

49 Court: Glor v. Switzerland (30/04/2009). 
gious convictions, because the chemists could have continued expressing them outside the scope of their professional activity.

It is important to note that, although this case could have been handled as a case of conscientious objection, the Court failed even to mention this expression in its inadmissibility decision. It simply limited to express that, under the French legislation, chemists are required to provide those products and that a refusal to do so could equal to an imposition of their beliefs on others. Thus, as in the opinion of the Court there was no interference with the religious freedom of the claimants, the demand was manifestly ill-founded.

"It considers that, as long as the sale of contraceptives is legal and occurs on medical prescription nowhere other than in a pharmacy, the applicants cannot give precedence to their religious beliefs and impose them on others as justification for their refusal to sell such products, since they can manifest those beliefs in many ways outside the professional sphere.

"It follows that the applicants' conviction for refusal to sell did not interfere with the exercise of the rights guaranteed by article 9 of the Convention and that the application is manifestly ill-founded within the meaning of article 35.3 of the Convention" ${ }^{50}$.

In some cases relating to abortion, the Court incidentally mentioned conscientious objection. In R.R. and $P$. and S. it was said that states are obliged to organise the health services system in such a way as to ensure that an effective exercise of the freedom of conscience of health professionals in the professional context does not prevent patients from obtaining access to services to which they are entitled ${ }^{51}$. Of course, this does not mean that a right to conscientious objection in such cases exists under the European Convention.

Finally, in a group of cases relating to hunting regulation, the Court stated that states were under a positive obligation to find solutions capable of accommodating the competing interests in order to reconcile the requirements of individual conscience with the public interest. In Chassagnou ${ }^{52}$ the Court found that the compulsory inclusion of landowners in a hunting organization, to which they transferred the hunting rights over their land, amounted to a violation of article 1 of Protocol 1 (right to peaceful enjoyment of one's possessions) taken

50 Court: Pichon and Sajous v. France (02/10/2001). On this case, see A. LAMAČKOVÁ, "Conscientious Objection in Reproductive Health Care: Analysis of Pichon and Sajousv. France", in European Journal of Health Law, 2008, 15-1, pp. 7-43. On conscientious objection of chemists, in particular conscientious objection to expend the morning-after pill, see R. M. ANDERSON, "Pharmacists and Conscientious Objection", in Kennedy Institute of Ethics Journal, 2006, 16- 4, pp. 379-396; A. GONZÁLEZ-VARAS, "La objeción de conciencia del farmacéutico en la jurisprudencia y su regulación legal en España”, in Revista General de Derecho Canónico y Derecho Eclesiástico del Estado, 2006, 15.

51 Court: R. R. v. Poland (26/05/2011), p. 206. Court: P. and S. v. Poland (30/10/2012), pp. 106-107.

52 Court: Chassagnou and others v. France (29/04/1999), Grand Chamber. 
alone and in conjunction with article 14 (prohibition of discrimination), as well as article 11 (freedom of association) taken alone and in conjunction with article 14, against those landowners who were opposed to hunting for ethical reasons. The applicants also complained of an infringement of their freedom of thought and conscience. The Court, however, considered that it was not necessary to consider the case under article 9. In a similar case, Schneider, the Court found a violation of articles 1 of Protocol 1 and 11 of the Convention ${ }^{53}$.

In these cases the Court did not say that there was a right to conscientious objection. Indeed, states could comply with European standards in many ways (for example establishing hunting associations on voluntary basis) and not necessarily through the recognition of a conscientious objector status. In a more recent case (Herrmann) which was decided after the change of the criterion that we will study below, the Grand Chamber maintained its point of view and found (against the previous decision of a Chamber) that the obligation to allow hunting on his land amounted to an unjustified interference with the applicant's right to the peaceful enjoyment of his property (article 1 of Protocol 1$)^{54}$. The Court considered unnecessary to examine separately the complaint under article 9. A partly dissenting judge, however, affirmed that the case was about conscientious objection to hunting ${ }^{55}$.

It is important to indicate, however, that even if the Court did not affirm that conscientious objection was the only way to comply with human rights standards, in all the cases a violation of the Convention was found because the landowners' convictions had not been respected. Indeed, in a very similar case the Court decided that there was no violation of the Convention because the applicant complained only on equality and property basis (article 14 taken in conjunction with article 1 of Protocol 1) and did not invoke any personal conviction against hunting ${ }^{56}$.

\subsection{The new criterion of the Court}

The attitude of the European Court changed radically in the Bayatyan case. This change dragged decades of precedents of the Commission which had been implicitly validated, through their silence, by the Court itself. The change was unexpected. Even if some scholars admitted that European Union legislation on Human Rights would force a progression in the Council of Europe system, they considered that it was still too early to be optimistic about the attitude of the Strasbourg court ${ }^{57}$.

53 Court: Scheneider v. Luxembourg (10/07/2007).

54 Court: Herrmann v. Germany (26/06/2012), Grand Chamber.

55 Court: Herrmann v. Germany (26/06/2012), Grand Chamber, partly concurring and partly dissenting opinion of judge Pinto de Albuquerque.

56 Court: Chabauty v. France (04/10/2012).

57 H. TAKEMURA, cit., p. 96. 
The case, decided in 2012, concerned a Jehovah's Witness convicted for his refusal to perform military service. The claimant requested review of the existing case-law on the grounds that the Convention is a living instrument. In the first instance, although the Court admitted that the Convention is an instrument which must be interpreted in the light of the current living conditions, it denied that there was place to revise the existing case-law. For the Court, article 4 provides clearly to each contracting party the choice of recognising conscientious objection or not, and it is not possible to rely on the fact that the majority of the states have recognised this right to say that the one that has not recognised it has violated its obligations under the Convention.

"The Court reiterates that the Convention is a living instrument which must be interpreted in the light of present-day conditions [...]. It is legitimate when deciding whether a certain measure is acceptable under one of its provisions to take account of the standards prevailing amongst the member states of the Council of Europe [...]. The Court does not deny that the majority of member states of the Council of Europe have indeed adopted laws providing for various forms of alternative service for conscientious objectors. At the same time, the Court cannot overlook the provisions contained in article 4.3.b of the Convention [...]. In the Court's opinion, since this article clearly left the choice of recognising conscientious objectors to each contracting party, the fact that the majority of the contracting parties have recognised this right cannot be relied upon to hold a contracting party which has not done so to be in violation of its Convention obligations. Consequently, as far as this particular issue is concerned, this factor cannot serve a useful purpose for the evolutive interpretation of the Convention. In such circumstances, the Court concludes that article 9, read in the light of Article 4.3.b, does not guarantee a right to refuse military service on conscientious grounds" 58 .

However, the Grand Chamber reversed the ruling of the first instance and with it all the precedents of the Commission on the matter ${ }^{59}$. There were several arguments. First of all, the Court expressed that the Travaux préparatoires of the Convention show that the sole aim of article 4.3.b, on which the Commission's interpretation was based, was to provide a definition of forced labour. Nevertheless, that article neither recognises nor excludes a right to conscientious objection, and therefore it should not have a limiting effect on the rights recognised in article 9 about freedom of conscience and religion ${ }^{60}$.

58 Court: Bayatyan v. Armenia (27/10/2009), first instance, p. 62-63. About this judgment see M. ALENDA SALINAS, "El Tribunal Europeo de Derechos Humanos ante la objeción de conciencia al servicio militar: ¿inmovilismo o falta de cobertura legal?”, in Revista General de Derecho Canónico y Derecho Eclesiástico del Estado, 2010, 22.

59 Court: Bayatyan v. Armenia (07/07/2011), Grand Chamber. About this decision see P. MUZNY, "Bayatyan v. Armenia: The Grand Chamber renders a grand judgment", in Human Rights Law Review, 2012, 12-1, pp. 135-147.

60 See Travaux préparatoires (Article 4), DH(62)10, 23. 
On the other hand, the Court considered that the restrictive interpretation of article 9 applied by the Commission was a reflection of the prevailing ideas in the historical moment in which the decisions had been made. However, many years had passed since the first case had been brought before the Commission. While it is true that the reasoning of the Commission was then confirmed in other cases, the Court took into account that the last decision dated back to 1995, and that since then many changes had occurred both at the domestic level of the member states of the Council of Europe and at the international level.

The Court insisted that the Convention is a living instrument which must be interpreted in the light of present conditions and prevailing ideas in democratic states. In particular, the Court must take into account the changing conditions in relation to the states and the emerging consensus that exists about certain standards. The Court noted that at the end of the 1980s and in the 1990s there had been a trend among European countries, both among those who were part of the Council of Europe and among those which joined the organization later, towards the recognition of conscientious objection.

Thus, when the Court was analysing the case, between 2002 and 2003, only four member states of the Council of Europe in addition to Armenia (which was the respondent state) did not envisage the possibility of conscientious objection. Even more: three of those states had recognised the right to conscientious objection in their constitutions, even though they had not passed regulatory laws yet. This situation was a proof of a consensus among the members of the Council of Europe on the issue. Furthermore, we must remember that subsequent to the facts of the case under consideration, two members of the Council of Europe passed laws implementing the right to conscientious objection in full mode. Even the respondent state recognised the right to conscientious objection after the facts of the case.

For all these reasons, the Court concluded that the claim should be considered only under the text of article 9 of the Convention, and not under this text in conjunction with article 4.3.b. As the applicant who refused military service was a member of the group of Jehovah's Witnesses, one could not doubt that the objection was motivated by his religious beliefs. And given the consensus between the member states of the Council of Europe regarding conscientious objection to military service, a state that had not yet recognised it had only a limited margin of appreciation in this respect. Therefore, to refuse the recognition of conscientious objection the state had to demonstrate that there was a social imperative that required the limitation of the right recognised in article 9.

However, in the Court's opinion, the imposition of a penalty to those who refuse to perform military service for reasons of conscience did not conduct a proper balance between the interests of individuals and the interests of society. Therefore it could not be considered as a necessary measure in a democratic society; even less if one considers that there were alternative solutions, as evi- 
denced by the experience of the vast majority of the member states of the Council of Europe.

As we can see, according to the new jurisprudence of the Strasbourg Court, conscientious objection can be found implicit in the broader right to freedom of conscience and religion.

Obviously this does not mean that any exemption to the fulfilment of a legal duty for reasons of conscience and religion is necessarily protected by article 9 of the Convention. The jurisprudence of the Court refers to a very specific case: the classic case of the conscientious objection to military service.

Indeed, in later cases very similar to the Bayatyan case, the Court consolidated the criterion. In Erçep ${ }^{61}$, Bukharatyan ${ }^{62}$, Tsaturyan ${ }^{63}$, Feti Demirtaş ${ }^{64}$ and Savd $a^{65}$ the Strasbourg Court addressed the situation of members of the religious group of Jehovah's Witnesses who had been convicted for refusing to comply with military service. In all of them, by application of the recently adopted criterion, it recognised the existence of a violation of religious freedom. The same violation was found in Tarhan in relation to a non-religious conscientious objector (the applicant was a pacifist opposed to militarism) ${ }^{66}$.

On the other hand, in the case of other legal duties the situation is much more dubious. It is likely that the Court is not willing to recognise conscientious objection in other areas, for which the consensus is much weaker (for example the medical conscientious objection to the practice of abortion, the conscientious objection of civil servants to marriages between persons of the same sex, or the case of tax conscientious objection).

In fact, despite this change of the Court on the conscientious objection to military service, the position is still restrictive in relation to the recognition of exceptions to general rules on grounds of freedom of conscience. In the Sessa case, decided after the second judgment of Bayatyan, the court judged that there was no reason for considering the existence of a restriction on religious freedom of a Jewish lawyer whom a domestic court had denied the change of the date of a hearing that coincided with a celebration of his religion. There had been no interference, said the Court, because the hearing had not prevented the lawyer to fulfil his religious duties and because the lawyer was able to be replaced in that hearing by another professional. Moreover, even assuming that there had been an interference, this would have been justified by the purpose of protection of the rights of third parties (the right to a reasonable duration of the judicial pro-

61 Court: Erçep v. Turkey (22/11/2011).

62 Court: Bukharatyan v. Armenia (10/01/2012).

63 Court: Tsaturyan v. Armenia (10/01/2012).

64 Court: Feti Demirtaşv v. Turkey (12/01/2012).

65 Court: Savda v. Turkey (12/06/2012).

66 Court: Tarhan v. Turkey (17/07/2012).

(C) Palacký University Olomouc, Czech Republic, 2013. ISSN 1213-8770 (print), ISSN: 2464-6601 (online). 
cess) and would have been proportionate to the purpose sought ${ }^{67}$. Moreover, as we have already said, cases about conscientious opposition to hunting were not treated as conscientious objection cases.

We should not conclude this section without mentioning that, as regards the European Social Charter, the European Committee of Social Rights has considered the situation of conscientious objectors to military service under Article 1.2 of the Charter. This article concerns the right of the worker to earn his living in an occupation freely entered upon. According to the Committee, the length of any alternative service required by objectors should be reasonable in comparison with the length of ordinary military service. For example, the Committee has found a length of alternative service which exceeds one-and-a-half times the length of military service to be excessive ${ }^{68}$.

\section{Conclusions}

For more than forty years the organs of the Council of Europe have promoted the recognition of conscientious objection to military service. Moreover, in the past decade the Council extended such promotion to other fields, such as the medical care. The promotion of conscientious objection has entailed many recommendations to the member states to recognise this legal mechanism in their internal legislation and practice.

Although the Council of Europe emphasised in various documents that conscientious objection should be considered as a derivation of freedom of conscience and religion as enshrined in article 9 of the European Convention on Human Rights, the European Court was reluctant to grant such recognition. For a long time the Court followed the Commission's precedents that considered conscientious objection to military service not to be mandatory under the Convention. The reason behind was that article 4 expressly admitted that states were free to recognise or not a substitute civil service. As regards other forms of conscientious objection, the Court was silent.

The 2011 Bayatyan case changed the situation radically. In it the Court established that conscientious objection to military service is implicit in article 9 of the Convention, which must be interpreted according to the circumstances of the time of its application. However, up to these days, the Court has not clearly pronounced about the existence of a right to conscientious objection in fields others than military service.

67 Court: Sessa v. Italy (03/04/2012).

68 Committee of Social Rights: Quaker Council for European Affairs (QCEA) v. Greece, Collective Complaint 8/2000. 